\title{
Quantifying the Acidity of an Ammonium-based Fertilizer in Containerized Plant Production
}

\author{
Connie N. Johnson ${ }^{1}$, Paul R. Fisher, and Jinsheng Huang \\ University of Florida, Environmental Horticulture, 1529 Fifield Hall, P.O. \\ Box 110670, Gainesville, FL 32611
}

Richard P. Vetanovetz

Sun Gro Horticulture, 16250 Hunters Run, Marysville, OH 43040

\author{
William R. Argo \\ Blackmore Company, 10800 Blackmore Avenue, Belleville, MI 48111
}

Additional index words. alkalinity, calcium carbonate, $\mathrm{pH}$, Pierre, peat, residual lime, substrate-pH

\begin{abstract}
In current horticultural practice, potential acidity or basicity of fertilizers is estimated using Pierre's method (PM) expressed in calcium carbonate equivalents (CCE) per unit weight of fertilizer. PM was developed using mineral field soil systems and may be inaccurate for quantifying fertilizer acidity in containerized plant production given the widespread use of soilless substrates and fertigation. The PM-predicted acidity of an ammonium-based fertilizer was compared against experimental data obtained when 'Ringo' geraniums [Pelargonium $\times$ hortorum (Bailey. L.H.)] and 'Super Elfin' impatiens [Impatiens wallerana (Hook. F.)] were grown in $70 \%$ peat:30\% perlite (v:v) limed with either hydrated limestone only (HL) or a combination of carbonate and hydrated limestone (CHL). Plants in 10-cm-diameter $(0.35 \mathrm{~L})$ containers were top-irrigated with a total of $2.0 \mathrm{~L}$ over 6 weeks using a $15.2 \mathrm{~N}-1.9 \mathrm{P}-12.6 \mathrm{~K}$ fertilizer $\left[100 \%\right.$ of nitrogen $(\mathrm{N})$ as $\left.\mathrm{NH}_{4}-\mathrm{N}\right]$ applied with each irrigation at $100 \mathrm{mg}$ N/L without leaching. According to PM, $61.8 \mathrm{meq}$ of fertilizer acidity was applied per liter of substrate. During the experiment, the $\mathrm{pH}$ of the substrate decreased from 7.05 to 4.41 for the HL substrate and from 7.14 to 5.13 for the CHL substrate. A corresponding drop in substrate-pH was observed when 37.1 (HL) or 43.3 (CHL) meq of CCE from $0.5 \mathrm{~N} \mathrm{HCl}$ was applied per liter of substrate in a laboratory titration of the same substrates without plants. Gasometric analysis of residual carbonate at Day 0 and at the end of the experiment quantified change in CHL substrate alkalinity with time, resulting in an estimated $30.7 \mathrm{meq}$ of neutralized alkalinity. Using an electroneutrality approach that assumed anion uptake $\left(\mathrm{NO}_{3}{ }^{-}, \mathrm{P}_{2} \mathrm{O}_{5}^{-}\right)$was basic, and cations $\left(\mathrm{NH}_{4}^{+}, \mathrm{K}^{+}\right)$were potentially acidic, nutrient analysis of the substrate at the beginning and end of the experiment estimated that an average 48.5 meq of acidity was contributed by the fertilizer. Experimentally measured acidity values were 13.1 to $31.1 \mathrm{meq} \cdot \mathrm{L}^{-1}$ of substrate lower for HL and CHL than those expected from PM, suggesting PM overestimated the amount of fertilizer acidity applied to the substrate. These results support the need for an alternative method to predict fertilizer acidity for plant production in soilless substrates.
\end{abstract}

Fertilizer type and concentration, plant species, water alkalinity, substrate components, and lime amendment dynamically affect substrate-pH during plant production. Fertilizer effect on substrate-pH occurs primarily through plant and microbial uptake of nutrients and the subsequent release of ions and/or root exudates along with other microbially induced

Received for publication 4 Dec. 2009. Accepted for publication 6 May 2010.

We thank the USDA-ARS Floriculture and Nursery Research Initiative, Blackmore Co., Greencare Fertilizers, Quality Analytical Laboratories, and Sun Gro Horticulture.

The use of trade names in this publication does not imply endorsement of the products named or criticism of similar ones not mentioned.

${ }^{1}$ To whom reprint requests should be addressed; e-mail johnscn@ufl.edu. processes such as nitrification (Marschner, 1995). Using nitrogen as an example, uptake of $\mathrm{NO}_{3}-\mathrm{N}$ can result in the release of $\mathrm{OH}^{-}$and $\mathrm{HCO}_{3}{ }^{-}$or coabsorption of a cation, whereas $\mathrm{H}^{+}$ ions are released with uptake of $\mathrm{NH}_{4}-\mathrm{N}$. The microbial conversion of $\mathrm{NH}_{4}-\mathrm{N}$ to $\mathrm{NO}_{3}-\mathrm{N}$ (nitrification) also produces $\mathrm{H}^{+}$.

Pierre's method ["PM," Pierre (1933)] is the standard used in the U.S. fertilizer industry to quantify the potential of a fertilizer to change soil acidity or alkalinity. The reported PM value for an acidic fertilizer, in units of calcium carbonate equivalents (CCE) of acidity per unit weight of fertilizer, refers to the CCE required to neutralize the acidity resulting from application of the fertilizer (Pierre, 1933). For basic reaction fertilizers, the CCE of basicity represents the basic residue in CCE left in the soil after application of the fertilizer.

Pierre's original methodology was modified and adopted by the Association of Official
Agricultural Chemists (AOAC) and is recognized as the official method to estimate the equivalent acidity/basicity of complete fertilizers (Tisdale and Nelson, 1966). The final official procedure was published by AOAC in 1970 with a minor revision in 1999 (AOAC, 1970, 1999). In brief, the fertilizer mixture is ground and a $0.25-$ to $1.0-\mathrm{g}$ dried sample is mixed with a sodium carbonate-sucrose solution and ashed in a furnace (at 575 to $600{ }^{\circ} \mathrm{C}$ ) to remove carbon and nitrogen compounds. After cooling, $\mathrm{HCl}$ is added for lime digestion (AOAC, 1970; Hignett, 1985). Once digested, the sample is titrated to $\mathrm{pH} 4.3$ using $0.5 \mathrm{~N}$ $\mathrm{NaOH}$ and compared with a similar titration of a blank sample of sodium carbonate-sucrose solution only (AOAC, 1970). The titrated difference between the blank sample and the fertilizer sample is the acidity or basicity of the fertilizer other than that contributed by nitrogen (Hignett, 1985). Table 1 shows the equivalent acidity or basicity factors for individual salt elements (Hignett, 1985), in which a positive value indicates the fertilizer sample is basic (non-acid-forming) and a negative value indicates the sample is acidic (Horat, 1939). For elements other than nitrogen or phosphorus, therefore, the acidity or basicity of a fertilizer salt is a direct measurement of its inorganic $\mathrm{acid} /$ base reaction in this titration and is independent of the soil or plant system.

The acidity or basicity factors of elements (Table 1), with the exception of nitrogen and phosphorus, is based on stoichiometry calculated by dividing the molecular weight of $\mathrm{CaCO}_{3}\left(100 \mathrm{~g} \cdot \mathrm{mol}^{-1}\right)$ by the equivalent weight of the element. The equivalent weight of the element is equal to its atomic weight ( $\mathrm{mw}$ ) for divalent elements and twice the atomic weight for monovalent elements. For example, the factor for potassium is determined as follows:

$$
\frac{\mathrm{mw} \mathrm{CaCO}_{3}}{2 \times \mathrm{mw} \mathrm{K}}=\frac{100}{2 \times 39.1}=+1.28
$$

Factors for nitrogen and phosphorus were based on empirical field studies by Pierre in the 1920s and 1930s that measured soil $\mathrm{pH}$ changes after fertilizer application, primarily using Cecil clay loam with an initial $\mathrm{pH}$ of 6 (Hignett, 1985). Pierre assumed that: 1) the acidifying effect is caused by all the sulfur and chlorine, one-third of the phosphorus, and onehalf of the nitrogen contained in the fertilizer; 2) calcium, magnesium, sodium, and potassium are base-forming elements; and 3) ammonium nitrogen is completely nitrified; nitrate nitrogen combined with bases such as sodium or calcium will have a net basic effect (Pierre, 1933; Tisdale et al., 1999; Tisdale and Nelson, 1966).

These assumptions merit critical evaluation when applied to use of water-soluble fertilizers in soilless container crop production. Pierre's method assumes nitrogen in fertilizers is provided as nitrate or is converted to nitrate through nitrification (Pierre, 1933). Rapid nitrification does indeed occur in container substrate above $\mathrm{pH} 5.5$, which is the typical growing range for most container crops (Argo and Biernbaum, 1997; Lang and Elliott, 1991). However, PM does not take into consideration acidification resulting from plant $\mathrm{NH}_{4}{ }^{+}$uptake 
Table 1. Equivalent acidity (negative) or basicity (positive) values in units of $\mathrm{kg}$ of $\mathrm{CaCO}_{3}$ per kilogram of element using Pierre's method (Hignett, 1985).

\begin{tabular}{lrrr}
\hline Element & Molecular wt (g) & Charge & $\begin{array}{r}\text { Equivalent acidity (-) } \\
\text { or basicity }(+)\end{array}$ \\
\hline Sulfur & \multicolumn{2}{c}{ Acid-forming elements } & -3.12 \\
Chlorine & 32.07 & -2 & -1.41 \\
Nitrogen & 35.45 & -1 & -1.79 \\
Phosphorus & 14.00 & \pm 1 & -1.61 \\
& 30.97 & -1 & \\
Calcium & & & +2.50 \\
Magnesium & 40.08 & Base-forming elements & +4.12 \\
Sodium & 24.31 & +2 & +2.18 \\
Potassium & 22.99 & +2 & +1.28 \\
\hline
\end{tabular}

or acidity from nitrification, and therefore it underestimates the lime-equivalent values required to neutralize the acid formed by the various nutrient salts in the fertilizer (Tisdale et al., 1999; Tisdale and Nelson, 1966).

Andrews (1954) maintained that all ammonium converted to nitrate creates acidity equivalent to $3.57 \mathrm{~kg}$ CCE per kilogram of nitrogen $(\mathrm{N})$ [calculated as mw of $\mathrm{CaCO}_{3} /(2 \times$ $\mathrm{mw}$ of $\mathrm{N}$ ) to correct for valence differences]. Andrews also argued that $3.57 \mathrm{~kg} \mathrm{CCE}$ base is leached from the soil along with every $\mathrm{kg}$ of $\mathrm{NO}_{3}-\mathrm{N}$ leached, and his analysis included multiple years of field trials and re-evaluation of Pierre's data. Andrews' assumptions result in differing acidity and basicity potentials for fertilizer salts than those of Pierre; he considered anhydrous ammonia to be twice as acidic as Pierre's estimate. Andrews' calculations indicate calcium nitrate is slightly acidic and potassium nitrate neutral, whereas Pierre's calculations indicate that they are both basic (Andrews, 1954; Tisdale and Nelson, 1966).

Pierre considered that $\mathrm{NH}_{4}{ }^{+}$uptake was possible but the amount was insignificant under normal agricultural conditions (Pierre, 1933). However, ammonium uptake is energetically favored over nitrate uptake when both $\mathrm{N}$ forms are supplied (Engels and Marschner, 1995; von Wiren et al., 2001). Plant species is an important factor to consider in $\mathrm{N}$ preference. For instance, plant species adapted to soils that are acidic or with low redox potential tend to have a greater rate of uptake of ammonium, whereas plant species adapted to calcareous soils have greater uptake of nitrate-nitrogen (Marschner, 1995 , p. 247). Ammonium follows an electrochemical gradient from apoplasm to symplasm without the requirement of metabolic energy. The exact path of $\mathrm{NH}_{4}^{+}$uptake is still unclear. It is believed that ammonium is taken up through an $\mathrm{NH}_{4}^{+}$uniport, $\mathrm{H}^{+}-\mathrm{NH}_{4}^{+}$symporter, diffusion, or ion channels through the plasma membrane (Engels and Marschner, 1995; von Wiren et al., 2001). In contrast to $\mathrm{NH}_{4}{ }^{+}, \mathrm{NO}_{3}{ }^{-}$ requires active transport from the apoplasm into the symplasm in association with $\mathrm{H}^{+}$fluxes through $\mathrm{H}^{+}-\mathrm{NO}_{3}{ }^{-}$symporters and $\mathrm{H}^{+}$-ATPase stimulation that maintains membrane electrical potential (Engels and Marschner, 1995). It is estimated that the absorption of $1 \mathrm{~mol}$ of $\mathrm{NO}_{3}{ }^{-}$ consumes 1 to $3 \mathrm{~mol}$ of ATP (Touraine et al., 2001). For that $1 \mathrm{~mol}^{\circ} \mathrm{NO}_{3}{ }^{-}$to be used by the plant, it must first be reduced to $\mathrm{NH}_{4}^{+}$in a process requiring $347 \mathrm{~kJ}$ of energy (Lewis,
1986). Low $\mathrm{NO}_{3}^{-}$concentration in the soil solution, low soil $\mathrm{pH}$, and low soil temperature have been shown to favor $\mathrm{NH}_{4}^{+}$uptake over $\mathrm{NO}_{3}^{-}$(Engels and Marschner, 1995).

The relative balance among nitrification, ammonium and nitrate uptake, and nutrient leaching, which in turn affect substrate acidity, is affected by factors such as species, irrigation method, soil microbial activity rate, plant evapotranspiration rate, and relative size of the plant and substrate volume. Pierre's assumption that only half of the $\mathrm{N}$ is actually acidforming is therefore an approximation based on the experimental conditions under which his model was calibrated.

Although on a strict inorganic chemistry basis using PM, cations such as calcium, magnesium, sodium, and potassium have a basic residue (Table 1), these cations can also have acidic behavior in a soil/crop system. Displacement of protons on exchange sites by cations causes a decrease in substrate-pH (Rippy and Nelson, 2005). Cation uptake by plants is an acidic or neutral process accompanied by anion uptake, base uptake, or in association with a proton pump (Marschner, 1995). Similarly, anion uptake by plants is a basic reaction despite the acidic factors for sulfur and chlorine in Table 1. Overall, the substrate-pH effect of a fertilizer salt is a balance between inorganic chemistry and the dynamic plant/microbial/soil system.

The objectives of this study were 1) to evaluate protocols to quantify fertilizer acidity or basicity in soilless substrates; and 2) to use these protocols to compare the reported fertilizer acidity from PM with the experimentally measured acidity when plants were grown with an ammonium-based, water-soluble fertilizer in a peat/perlite substrate.

\section{Materials and Methods}

\section{Greenhouse substrate experiments}

In Spring 2007, a 70\%:30\% (v:v) peat: perlite substrate was mixed with dolomitic hydrated limestone $\left[97 \% \mathrm{Ca}(\mathrm{OH})_{2} \cdot \mathrm{MgO}\right.$, $92 \%$ of which passed through a $45-\mu \mathrm{m}$ screen; National Lime and Stone, Findlay, OH; reported acid-neutralizing value of $161 \%$ $\mathrm{CCE}]$ at a rate of $2.8 \mathrm{~kg} \cdot \mathrm{m}^{-3}$ to raise substrate-pH to 7.04. One week later, the substrate was divided with half remaining amended with hydrated lime only (HL) and half amended with additional dolomitic carbonate limestone (CHL) $\left[\mathrm{CaMg}\left(\mathrm{CO}_{3}\right)_{2}\right.$, Lawn \&
Garden limestone ${ }^{\mathrm{TM}}$; Oldcastle Stone Products $\AA$, Thomasville, PA] at a rate of 2.22 $\mathrm{kg} \cdot \mathrm{m}^{-3}$. The additional dolomitic carbonate lime in the CHL substrate was added to provide residual carbonate and substrate-pH buffering throughout the experiment. The peat source used in the research substrates was Canadian Sphagnum peat (Sun Gro Horticulture, Vancouver, Canada) with long fibers and little dust (von Post scale 1 to 2; Puustjarvi and Robertson, 1975). The HL and CHL substrates were placed in $10-\mathrm{cm}, 350-\mathrm{mL}$ containers. Container capacity was $255 \mathrm{~mL}$ or $73.0 \%$ of container volume. Plugs of 'Ringo Scarlet' and 'Ringo Coral' geraniums [Pelargonium Xhortorum (Bailey. L.H.)] and 'Super Elfin White' and 'Super Elfin Salmon' impatiens [Impatiens wallerana (Hook. F.)] were transplanted into the containers. The geraniums had been seed-propagated in 105-celled plug trays and the impatiens in 162-celled plug trays.

The containers received a total of 20 irrigations in 6 weeks applied to the substrate surface. They were irrigated each time with $100 \mathrm{~mL}$ of an acidic fertilizer solution consisting of $100 \mathrm{~N}-$ $12.8 \mathrm{P}-83.3 \mathrm{~K}-107.8 \mathrm{~S}-75.8 \mathrm{Cl} \mathrm{mg} \cdot \mathrm{L}^{-1}(100 \%$ total $\mathrm{N}$ as $\mathrm{NH}_{4}-\mathrm{N}$ ) and an Fe-EDDHA-chelate micronutrient blend of $1 \mathrm{Fe}-0.25 \mathrm{~B}-0.25 \mathrm{Cu}-$ $0.5 \mathrm{Mn}-0.1 \mathrm{Mo}-0.5 \mathrm{Zn} \mathrm{mg} \cdot \mathrm{L}^{-1}$ (Greencare Fertilizers, Inc., Kankakee, IL) in deionized water. Saucers were placed under each container to allow reabsorption of any leachate. The plants were grown in a polycarbonate-covered greenhouse for 6 weeks with average temperatures of $22.4 \pm 4.3{ }^{\circ} \mathrm{C}$ and average photosynthetically active radiation light of $10.9 \pm 3.0 \mathrm{~mol} \cdot \mathrm{m}^{-2} \cdot \mathrm{d}^{-1}$ (daily mean $\pm \mathrm{SD}$ )

The greenhouse experiment was a randomized complete block design with a factorial of two substrates $(\mathrm{HL}$ and $\mathrm{CHL}) \times$ two species (geraniums and impatiens) $\times$ two cultivars (for each species). There were three blocks (greenhouse benches). Each block included one replicate (or container) of all substrate, species, and cultivar combinations for a total of three replicates (containers) per variable measured each sample date. Data were collected for all measurement variables over the course of 6 weeks from destructively sampled containers (i.e., there were no repeated measurements on the same plants). Substrate-pH and electrical conductivity (EC) were measured weekly (Weeks 0 to 6) using saturated media extraction (SME) (Rippy and Nelson, 2005; Warncke, 1986). SME solution samples were also analyzed for nutrient content by Quality Analytical Laboratories (Panama City, FL) using inductively coupled plasma (for phosphorus and potassium) and Lachat ${ }^{\circledR}$ (for $\mathrm{NH}_{4}^{+}$and $\mathrm{NO}_{3}^{-}$). Changes in residual carbonate concentration were measured biweekly (Weeks 0, 2, 4, 6) using a gasometric analysis method (Huang et al., 2007). The acid drench experiment was conducted in a laboratory using the same HL and CHL substrates used in the greenhouse experiment. There were six drench rates (treatments) with four replicates each. Substrate-pH data were collected immediately before and $7 \mathrm{~d}$ after drenching for regression analysis. All data were analyzed using SAS PROC GLM (SAS 
Institute, 2001) and means were separated using Tukey's honestly significant difference $(\alpha=0.05)$.

\section{Methods for measuring fertilizer acidity or alkalinity}

Pierre's method. The acidity of each salt that comprised the ammonium fertilizer was computed and summed using the factors shown in Table 1. The fertilizer blend consisted of $7.26 \%$ monoammonium phosphate $\left(\mathrm{NH}_{4} \mathrm{H}_{2} \mathrm{PO}_{4}\right), 68.16 \%$ ammonium sulfate $\left[\left(\mathrm{NH}_{4}\right)_{2} \mathrm{SO}_{4}\right]$, and $24.56 \%$ potassium chloride $(\mathrm{KCl})$ by weight. To calculate the acidity of the individual salts, the following equations were used:

(A)

$$
\begin{aligned}
\frac{\text { mw of element }}{\text { mw of salt }} & \times \text { equivalent acidity or } \\
& \text { basicity for element in } \\
& \text { Table } 1 \times 1000 \mathrm{~kg}
\end{aligned}
$$

$=\mathrm{kg}$ of $\mathrm{CaCO}_{3}$ acidity or basicity for element per $1000 \mathrm{~kg}$ (metric tonne) of fertilizer salt.

(A) $\times$ percent mass of fertilizer salt in fertilizer blend $=\mathrm{kg}$ of $\mathrm{CaCO}_{3}$ acidity or basicity per metric tonne of nutrient in fertilizer blend.

$$
\begin{aligned}
& \mathrm{NH}_{4} \mathrm{H}_{2} \mathrm{PO}_{4}: \\
& \mathrm{N}: \frac{14.01[\mathrm{~N}]}{115.01} \times(-1.79) \times 1000 \mathrm{~kg}= \\
& -217.89 \mathrm{~kg} \mathrm{CCE} \\
& \mathrm{P}: \frac{30.97[\mathrm{P}]}{115.01} \times(-1.61) \times 1000 \mathrm{~kg}= \\
& \quad-433.58 \mathrm{~kg} \mathrm{CCE}
\end{aligned}
$$

The negative $\mathrm{CCE}$ values indicate that the elements of $\mathrm{N}$ and phosphorus in $\mathrm{NH}_{4} \mathrm{H}_{2} \mathrm{PO}_{4}$ are acidic. Total calculated acidity from 1000 $\mathrm{kg}$ (metric tonne) of $\mathrm{NH}_{4} \mathrm{H}_{2} \mathrm{PO}_{4}$ was equivalent to $651.47 \mathrm{~kg} \mathrm{CaCO}_{3}(217.89 \mathrm{~kg}+$ $433.58 \mathrm{~kg}=651.47 \mathrm{~kg}$ ), which contributed $47.28 \mathrm{~kg} \mathrm{CaCO}_{3}$ acidity per tonne of $15.2 \mathrm{~N}-$ $1.9 \mathrm{P}-12.6 \mathrm{~K}$ fertilizer $(7.26 \% \times 651.47 \mathrm{~kg}$ of $\mathrm{CaCO}_{3}=47.28 \mathrm{~kg}$ ).

$$
\begin{aligned}
& \left(\mathrm{NH}_{4}\right)_{2} \mathrm{SO}_{4}: \\
& \mathrm{N}: \frac{14.01 \times 2[\mathrm{~N}]}{132.12} \times(-1.79) \\
& \quad \times 1000 \mathrm{~kg}=-379.56 \mathrm{~kg} \mathrm{CCE} \\
& \mathrm{S}: \frac{32.07[\mathrm{~S}]}{132.12} \times(-3.12) \times 1000 \mathrm{~kg}= \\
& \quad-757.25 \mathrm{~kg} \mathrm{CCE}
\end{aligned}
$$

The negative $\mathrm{CCE}$ values indicate that the elements of $\mathrm{N}$ and sulfur in $\left(\mathrm{NH}_{4}\right)_{2} \mathrm{SO}_{4}$ are acidic. Total calculated acidity was equivalent to $1136.61 \mathrm{~kg} \mathrm{CaCO} 3$ per tonne of $\left(\mathrm{NH}_{4}\right)_{2} \mathrm{SO}_{4}$ $(379.56 \mathrm{~kg}+757.25 \mathrm{~kg}=1136.61 \mathrm{~kg})$, which accounted for $774.92 \mathrm{~kg}$ acidity per tonne of $15.2 \mathrm{~N}-1.9 \mathrm{P}-12.6 \mathrm{~K}$ fertilizer $(68.16 \% \times$ $1136.61 \mathrm{~kg}=774.92 \mathrm{~kg}$ ).

$$
\begin{aligned}
& \mathrm{KCl}: \\
& \begin{aligned}
\mathrm{K} & : \frac{39.09[\mathrm{~K}]}{74.55} \times(+1.28) \\
& \times 1000 \mathrm{~kg}=671.34 \mathrm{~kg} \mathrm{CCE} \\
\mathrm{Cl} & : \frac{35.45[\mathrm{Cl}]}{74.55} \times(-1.41) \\
& \times 1000 \mathrm{~kg}=-670.48 \mathrm{~kg} \mathrm{CCE}
\end{aligned}
\end{aligned}
$$

The net effect of $\mathrm{KCl}$ is therefore $\approx 0 \mathrm{~kg}$ $\mathrm{CaCO}_{3}$ acidity according to $\mathrm{PM}$ assumptions.

Based on previous calculation, the $15.2 \mathrm{~N}-$ $1.9 \mathrm{P}-12.6 \mathrm{~K}$ fertilizer had a net acidity of $822.20 \mathrm{~kg} \mathrm{CaCO}_{3}\left[47.28 \mathrm{~kg}\right.$ from $\mathrm{NH}_{4} \mathrm{H}_{2} \mathrm{PO}_{4}$ $+774.92 \mathrm{~kg}$ from $\left(\mathrm{NH}_{4}\right)_{2} \mathrm{SO}_{4}+0 \mathrm{~kg}$ from $\mathrm{KCl}$ ] per tonne of fertilizer. To convert kilograms $\mathrm{CaCO}_{3}$ acidity per tonne of fertilizer to pounds $\mathrm{CaCO}_{3}$ acidity per U.S. ton of fertilizer, as typically reported on fertilizer labels, the following conversion is made:

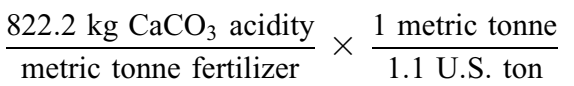
$\times \frac{2.2 \mathrm{lbs}}{1 \mathrm{~kg}}=1644.39 \mathrm{lbs}$ acidity/U.S. ton

Milliequivalents $\mathrm{CaCO}_{3}$ (CCE) acidity applied per liter of substrate during each irrigation were calculated as:

$$
\begin{aligned}
& \text { (A) } \frac{1}{0.152 \% \mathrm{~N}} \times 100=6.58 \mathrm{~g} \\
& \text { fertilizer for every } 1 \mathrm{~g} \mathrm{~N} .
\end{aligned}
$$

(B) $100 \mathrm{mg} \cdot \mathrm{L}^{-1} \mathrm{~N}$ applied $\times 0.1 \mathrm{~L}$ of fertilizer applied $=10.0 \mathrm{mg} \mathrm{N}$ applied per irrigation.

$$
\text { (C) } \frac{(\mathrm{A}) \times(\mathrm{B})}{1000 \mathrm{mg}}=0.066 \mathrm{~g} \text { fertilizer applied. }
$$$$
\text { (D) } \frac{822.2 \mathrm{~kg} \mathrm{CaCO} \text { calculated }}{1000 \mathrm{~kg} \text { (metric ton })}
$$$$
\times(\mathrm{C})=0.054 \mathrm{~g} \text { of }
$$$$
\mathrm{CaCO}_{3} \text { acidity applied. }
$$

(E) (D) $\times 2.86$ containers per $\mathrm{L}$ of substrate $\times 20$ meq per $\mathrm{g} \mathrm{CaCO}_{3}=3.09$ meq $\mathrm{CCE}$

acidity applied per liter substrate per irrigation. The molecular weight of $\mathrm{CaCO}_{3}$ is $100.08 \mathrm{~g} \cdot \mathrm{mol}^{-1}$. One mole of $\mathrm{CaCO}_{3}$ neutralizes $2 \mathrm{~mol}$ of acid. To neutralize 1 mole of acid, half the weight of $\mathrm{CaCO}_{3}(50.04 \mathrm{~g})$ is needed. The milliequivalent of CCE in $1 \mathrm{~g}$ of $\mathrm{CaCO}_{3}$ is determined as: $1000 \mathrm{mg} / 50.04=20$ meq CCE.
Because 20 applications $(2.0 \mathrm{~L})$ of the 100 $\mathrm{mg} \cdot \mathrm{L}^{-1} \mathrm{~N} 15.2 \mathrm{~N}-1.9 \mathrm{P}-12.68 \mathrm{~K}$ ammonium fertilizer solution was made, a total of 61.8 meq of acidity was applied per liter of substrate during the 6-week experiment. Of this total acidity $(\mathrm{N}$, phosphorus, sulfur, and chlorine $=2458.76 \mathrm{~kg}$ CCE), the relative percentage contribution to acidity estimated using PM for each nutrient was $24 \% \mathrm{~N}, 18 \%$ phosphorus, $31 \%$ sulfur, and $27 \%$ chlorine, whereas all of the basicity was contributed by potassium.

Gasometric method. Reduction in carbonate alkalinity in the substrate with time was used to quantify acidification during the experiment period. The gasometric procedure described by Huang et al. (2007) measures carbonates and bicarbonates but not other sources of substrate alkalinity such as phosphates and cation exchange capacity that are present in substrates. In this procedure, the addition of $\mathrm{HCl}$ to substrate containing carbonate-based limestones releases $\mathrm{CO}_{2}$ gas as a byproduct, causing a volume displacement of solution in the gasometric system apparatus. This displacement by $\mathrm{CO}_{2}$ can be measured and related to moles of $\mathrm{CaCO}_{3}$ using the Ideal Gas Law. This procedure was shown to yield reliable estimations of CCE by Huang et al. (2007) for recovery of incorporated $\mathrm{CaCO}_{3}$. The gasometric procedure was used to measure initial and final residual carbonate lime present in the substrate. In the procedure, a $50-\mathrm{mL}$ sample of substrate was placed in a 1-L flask with $75 \mathrm{~mL}$ deionized water. A stir bar was placed inside the flask that was then connected to a closed gasometric system. Twenty-five milliliters of $6 \mathrm{M} \mathrm{HCl}$ was then dispensed into the flask and the resulting $\mathrm{CO}_{2}$ gas released from the reaction of $\mathrm{HCl}$ with carbonates and bicarbonates was measured by volume displacement of a solution. Temperature and pressure readings were recorded before and after testing a sample. The total reaction time for each sample was $30 \mathrm{~min}$ or when $\mathrm{CO}_{2}$ volume readings were steady for at least 5 min, after which the final $\mathrm{CO}_{2}$ volume was measured. The volume of $\mathrm{CO}_{2}$ displacement was used to determine the amount of $\mathrm{CaCO}_{3}$ present using the Ideal Gas Law (Huang et al., 2007). The change in $\mathrm{CaCO}_{3}$, or the amount of carbonate neutralized, was assumed to be the amount of acidity that had been added to the substrate using the equation:

$$
\begin{aligned}
& {\left[\mathrm{g} \mathrm{CaCO}_{3} / \mathrm{L}_{(\text {initial })}-\mathrm{g} \mathrm{CaCO}_{3} / \mathrm{L}_{(\text {final })}\right]} \\
& \quad \times 20 \text { meq per } \mathrm{g} \mathrm{CaCO}_{3}= \\
& \text { milliequivalent } \mathrm{CCE} \text { per } \mathrm{L} \text { of substrate. }
\end{aligned}
$$

Acid drench method. Water alkalinity is normally calculated by titrating with mineral acid to a target $\mathrm{pH}$ of 4.5 (Bailey, 1996). The same principle was adapted in an acid drench method to measure alkalinity in the substrate (Huang et al., 2009). Samples of $350 \mathrm{~mL}$ of the HL and CHL substrates were placed in plastic bags and kept at container capacity for $7 \mathrm{~d}$ (without plants), and substrate-pH was measured. Hydrochloric acid $(0.5 \mathrm{~N})$ was then 
added at volumes of $0,14,28,42,56$, and 70 $\mathrm{mL}$, resulting in $0,20,40,60,80$, or 100 meq of acid per L of substrate, respectively. Substrate$\mathrm{pH}$ was measured $7 \mathrm{~d}$ after acid application with four replicates. The change in substrate$\mathrm{pH}(\Delta \mathrm{pH})$ was analyzed using quadratic regression to generate $\Delta \mathrm{pH}-$ milliequivalent relationships for each substrate. The $\Delta \mathrm{pH}-$ milliequivalent regression curves were then used to estimate the equivalent milliequivalent of acidity from fertilizer in the greenhouse trial with geranium and impatiens using the measured change in substrate-pH from the beginning to the end of the crop.

Charge balance method. One approach to quantify acidity or basicity of a fertilizer is based on the principle of electroneutrality, whereby plant uptake of positively or negatively charged nutrient ions is counterbalanced with the exchange between plant and substrate of protons $\left(\mathrm{H}^{+}\right)$, hydroxyl $\left(\mathrm{OH}^{-}\right)$, carbonate $\left(\mathrm{CO}_{3}{ }^{2-}\right)$, or other root exudates (Marschner, 1995). In this context, the milliequivalent of cations taken up by plant roots causes an equal milliequivalent of acidity to be added to the substrate, whereas anion uptake causes an equivalent basic reaction.

Soil processes should also be considered in the context of charge balance, particularly nitrification. The oxidation of 1 meq of $\mathrm{NH}_{4}^{+}$ will produce a net acidity of $1 \mathrm{meq}$ as long as the end product $\mathrm{NO}_{3}{ }^{-}$is also taken up by a plant with a net charge balance equal to direct plant uptake of $\mathrm{NH}_{4}{ }^{+}$:

$$
\begin{gathered}
1 \mathrm{NH}_{4}^{+}+11 / 2 \mathrm{O}_{2} \text { (Nitrosomonas) } \\
\rightarrow 1 \mathrm{NO}_{2}{ }^{-}+1 \mathrm{H}_{2} \mathrm{O}+2 \mathrm{H}^{+} \\
1 \mathrm{NO}_{2}{ }^{-}+1 / 2 \mathrm{O}_{2} \text { (Nitrobacter) } \rightarrow 1 \mathrm{NO}_{3}{ }^{-}
\end{gathered}
$$

When determining the net milliequivalent of acidity created from application and uptake of fertilizer using charge balance, the acidity estimate of total nutrients applied must be corrected for those applied nutrients that are not taken up by the plant (accumulating in the substrate) or that change form (such as the $\mathrm{NO}_{3}{ }^{-}$product of nitrification).

For the charge balance method used in this study, acidity estimates were based only on $\mathrm{N}$, phosphorus, and potassium because these three macronutrients comprised the bulk of the experimental fertilizer, are among the elements taken up in the greatest quantity by plants, and thus would be expected to have the greatest influence on acidity (Epstein and Bloom, 2005). Calcium (Ca) and magnesium $(\mathrm{Mg})$ were not included in the acidity estimates because for each milliequivalent of $\mathrm{H}^{+}$ released by a milliequivalent of $\mathrm{Ca}$ and $\mathrm{Mg}$, a milliequivalent of acid neutralizing $\mathrm{HCO}_{3}{ }^{-}$ or $\mathrm{CO}_{3}$ was applied, thus neutralizing the $\mathrm{Ca}$ and $\mathrm{Mg}$ addition. Milliequivalents of acidity or basicity derived from the portion of nutrients applied but not taken up or nitrified can be determined using the change in nutrient concentration in the substrate. Substrate analysis has a key advantage over tissue analysis because total $\mathrm{N}$ uptake by plant tissue does not differentiate between nitrate and ammonium forms. These estimations include the assumption that no leaching, volatilization, or other loss of nutrients occurred. To calculate the net milliequivalent of acidity (or basicity) of fertilizer nutrients applied and taken up or nitrified (as determined by nutrient change in the substrate), the following series of calculations were made:

1. Calculate total milliequivalent of acidity/basicity of nutrient applied:

$$
\begin{aligned}
& \text { (a) } \frac{\% \text { nutrient }}{\% \text { Total } \mathrm{N}} \times 100=\mathrm{mg} \cdot \mathrm{L}^{-1} \\
& \text { of fertilizer applied. }
\end{aligned}
$$

(b) (a) $\times$ L of fertilizer solution applied per container $=\mathrm{mg}$ applied per container.

(c) (b) $\times 2.86$ containers $\cdot \mathrm{L}^{-1}$ substrate $=\mathrm{mg}$ applied/L substrate.

$$
\begin{aligned}
& \text { (d) } \frac{(\mathrm{c})}{\text { atomic wt. of nutrient }} \\
& \quad=\text { millimoles per L of substrate. }
\end{aligned}
$$

(e) $(d) \times$ valence of nutrient salt $=$ milliequivalent of acid (or base)/L substrate.

2. Subtract milliequivalent of potential acidity/basicity of nutrient not taken up (or nitrified) based on measured substrate nutrient concentration. There was no nitrate-nitrogen applied in the fertilizer, so all nitrate measured in the substrate was assumed to be equivalent to the amount of ammonium nitrogen nitrified and not taken up.

(a) $\mathrm{mg} \cdot \mathrm{L}^{-1}$ nutrient $_{(\text {final })}-\mathrm{mg} \cdot \mathrm{L}^{-1}$ nutrient $_{\text {(initial) }}=\mathrm{mg} \cdot \mathrm{L}^{-1}$ change in nutrient per container.

(b) (a) $\times 2.86$ containers $/ \mathrm{L}$ substrate $=\mathrm{mg}$ change in nutrient $/ \mathrm{L}$ substrate.

$$
\begin{aligned}
& \text { (c) } \frac{(b)}{\text { atomic wt. of nutrient }}=\text { millimoles } \\
& \text { not take up per L of substrate. }
\end{aligned}
$$

(d) $(c) \times$ valence of nutrient ion $=$ milliequivalent of potential acid (or base)/L substrate from nutrient not taken up or nitrified.

(e) milliequivalent of acid (base) applied milliequivalent of acid (base) not taken up $=$ milliequivalent of acid (base) from nutrient taken up.

\section{Statistical analysis}

Fertilizer acidity data estimated from all the methods were subject to analysis of variance analysis using SAS PROC GLM (SAS Institute, 2001). Means were separated using $95 \%$ confidence interval by substrate types (for gasometric and acid drench methods) or by species (for charge balance methods).

\section{Results and Discussion}

With respect to all data measured in the greenhouse experiment, cultivar within each of the two species did not affect any treatment comparisons. Data of cultivars within each species were therefore combined within species and further analyzed for species and/or substrate influences.

\section{Substrate-pH and electrical conductivity}

Substrate-pH did not differ between species with time $(P=0.1706)$. As expected, residual carbonate limestone in the $\mathrm{CHL}$ substrate resulted in less $\mathrm{pH}$ change (i.e., greater $\mathrm{pH}$ buffering) than the HL substrate $(P=0.0001)$ (Fig. 1). After 6 weeks, substrate-pH decreased by 2.01 units from the starting $\mathrm{pH}$ of 7.14 in the CHL substrate, compared with 2.64 units below the initial $\mathrm{pH}$ of 7.05 in the HL substrate. Although the additional carbonate limestone in the CHL substrate provided some buffering against decreasing $\mathrm{pH}$, the $\mathrm{pH}$ of both the $\mathrm{CHL}$ and HL substrates dropped low enough to result in visual micronutrient toxicity symptoms in the geraniums, which commonly occurs below pH 6 (Argo and Fisher, 2002).

Substrate EC differed between species $(P=$ $0.0011)$ but not substrate type $(P=0.2714)$. Substrate EC increased with time from an average 1.7 to $3.5 \mathrm{dS} \cdot \mathrm{m}^{-1}$. It finished 0.5 
$\mathrm{dS} \cdot \mathrm{m}^{-1}$ higher for geranium than impatiens. EC levels remained within acceptable to optimum values for container plants reported by Warncke (1995).

\section{Substrate nitrogen-phosphorus- potassium}

Substrate nutrient data differed between species for $\mathrm{NO}_{3}, \mathrm{NH}_{4}$, and phosphorus $(\mathrm{P})$ $(P \leq 0.0003)$ but not potassium $(\mathrm{K})(P=$ $0.3531)$. The residual and non-residual substrates differed only in $\mathrm{NO}_{3}$ concentration $(P=0.0047)$. There was also a species $\times$ substrate interaction for $\mathrm{NO}_{3}(P=0.0250)$, but substrate nutrient data for both substrates were combined for each species in the charge balance method results and calculations shown in Table 2 for a simpler illustration of the method.

Pierre's method. Using the previously shown calculations, 3.1 meq CCE of acidity per liter of substrate was introduced into the substrates with each fertigation event. During the course of 6 weeks, an estimated $61.8 \mathrm{meq}$ CCE of acidity was contributed by the fertilizer per liter of substrate (Fig. 2A).

Gasometric method. Because the gasometric method measures residual carbonate, only the CHL substrate (which included carbonate limestone) was analyzed. There were no statistically significant differences between species $(P>0.05)$ at any week, so data were combined within each measurement date. Residual calcium carbonate lime measured in the substrate decreased with time (Fig. 2B). Residual carbonate CCE decreased to $27.1 \mathrm{meq} / \mathrm{L}$ of substrate from the initial $57.8 \mathrm{meq}$ CCE of carbonate measured.
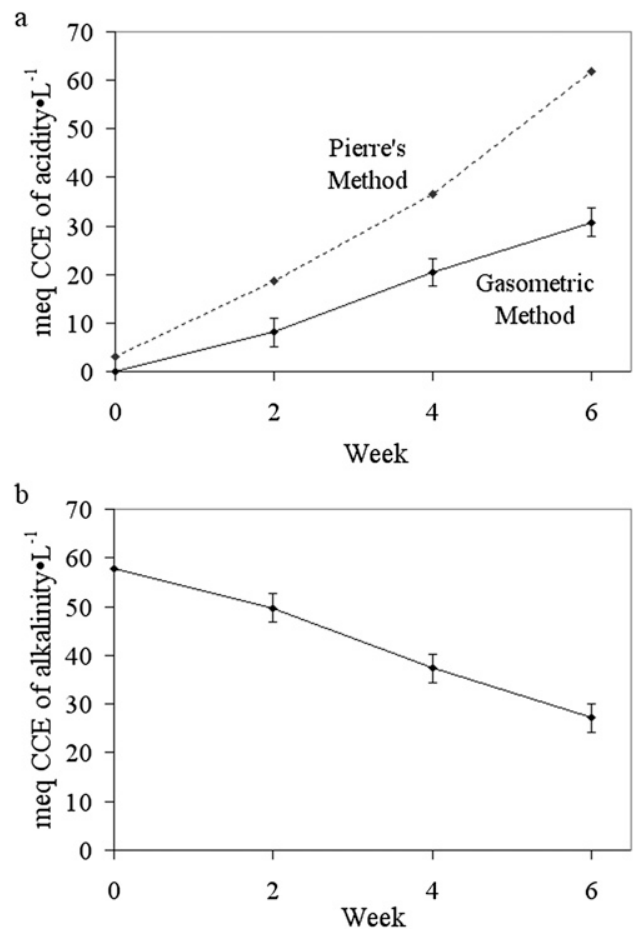

Fig. 2. (A) Milliequivalents (meq) of calcium carbonate (CCE) of acidity from $15.2 \mathrm{~N}-1.9 \mathrm{P}-12.6 \mathrm{~K}(100 \%$ $\mathrm{N}$ as $\mathrm{NH}_{4}-\mathrm{N}$ ) fertilizer applied per liter of substrate determined by Pierre's method (PM) and meq of CCE of carbonate neutralized with time as determined by change in residual carbonate using the gasometric method. (B) Milliequivalents of residual CCE in CHL (carbonate and hydrated lime) substrate measured with time using the gasometric method used to calculate the gasometric curve in $\mathbf{A}$. With each fertigation, $100 \mathrm{~mL}$ of $100 \mathrm{mg} \cdot \mathrm{L}^{-1} \mathrm{~N}$ ammonium fertilizer was applied 20 times per $10-\mathrm{cm}$ diameter container, which according to PM provided a total of 61.8 of CCE per liter of substrate (3.09 meq per irrigation). Error bar represents $95 \%$ confidence interval of each data point and symbols represent the mean of 12 replicates.

Table 2. Fertilizer acidity calculated by the charge balance method which assumes cations $(+)$ are acidic and anions $(-)$ are basic. ${ }^{\mathrm{z}}$

\begin{tabular}{|c|c|c|c|c|c|c|c|c|}
\hline \multirow[b]{2}{*}{ Total acidity applied from N-P-K } & \multicolumn{4}{|c|}{ Geraniums } & \multicolumn{4}{|c|}{ Impatiens } \\
\hline & $\mathrm{NO}_{3}-\mathrm{N}(-)$ & $\mathrm{NH}_{4}-\mathrm{N}(+)$ & $\mathrm{P}(-)$ & $\mathrm{K}(+)$ & $\mathrm{NO}_{3}-\mathrm{N}(-)$ & $\mathrm{NH}_{4}-\mathrm{N}(+)$ & $\mathrm{P}(-)$ & $\mathrm{K}(+)$ \\
\hline mg nutrient per L solution applied (a): & 0.0 & 100.0 & 12.5 & 83.0 & 0.0 & 100.0 & 12.5 & 83.0 \\
\hline $\begin{array}{l}1 \mathrm{~L} / 350 \mathrm{~mL} \text { per container }=2.9 \text { containers } \\
\text { per } \mathrm{L} \text { substrate }(\mathrm{d})(\mathrm{c}) \times(\mathrm{d})=\mathrm{mg} \text { nutrient } \\
\text { applied per L substrate }(\mathrm{e}) \text { : }\end{array}$ & 0.0 & 571.4 & 71.4 & 474.1 & 0.0 & 571.4 & 71.4 & 474.1 \\
\hline cationic (anionic) charge of nutrient ion (h) & -1.0 & 1.0 & -1.0 & 1.0 & -1.0 & 1.0 & -1.0 & 1.0 \\
\hline \multirow{2}{*}{$\begin{array}{l}(\mathrm{g}) \times(\mathrm{h})=\text { milliequivalent acid (base) from } \\
\text { nutrient per L substrate (i) }\end{array}$} & 0.0 & 40.8 & -2.3 & 12.1 & 0.0 & 40.8 & -2.3 & 12.1 \\
\hline & \multicolumn{3}{|c|}{ Net $\mathrm{N}-\mathrm{P}-\mathrm{K}$ acidity $=$} & 50.6 & \multicolumn{3}{|c|}{ Net $\mathrm{N}-\mathrm{P}-\mathrm{K}$ acidity $=$} & 50.6 \\
\hline Acidity corrected for substrate charge balance & $\mathrm{NO}_{3}-\mathrm{N}$ & $\mathrm{NH}_{4}-\mathrm{N}$ & $\mathrm{P}$ & $\mathrm{K}$ & $\mathrm{NO}_{3}-\mathrm{N}$ & $\mathrm{NH}_{4}-\mathrm{N}$ & $\mathrm{P}$ & $\mathrm{K}$ \\
\hline $\begin{array}{l}(\mathrm{k})-(\mathrm{j})=\text { change in } \mathrm{mg} \text { nutrient per } \mathrm{L} \text { of } \\
\text { SME (l) }\end{array}$ & 24.8 & 44.2 & 9.7 & 89.8 & -5.1 & 4.4 & 4.7 & 84.1 \\
\hline $\begin{array}{l}(1) \times(0.73 \mathrm{~L} \text { SME per } \mathrm{L} \text { of substrate })=\text { change } \\
\text { in } \mathrm{mg} \text { nutrient per } \mathrm{L} \text { of substrate }(\mathrm{m})\end{array}$ & 18.1 & 32.3 & 7.1 & 65.5 & -3.7 & 3.2 & 3.5 & 61.4 \\
\hline $\begin{array}{l}{[(\mathrm{m}) \div(\mathrm{f})] \times(\mathrm{h})=\text { milliequivalent of nutrient }} \\
\text { not taken up per liter of substrate }(\mathrm{n})\end{array}$ & -1.3 & 2.3 & -0.2 & 1.7 & 0.3 & 0.2 & -0.1 & 1.6 \\
\hline \multirow{2}{*}{$\begin{array}{l}\text { (i) }-(n)=\text { milliequivalent nutrient assumed } \\
\text { taken up or nitrified }\end{array}$} & 1.3 & 38.5 & -2.1 & 10.5 & -0.3 & 40.6 & -2.3 & 10.6 \\
\hline & & \multicolumn{2}{|c|}{ Net $\mathrm{N}-\mathrm{P}-\mathrm{K}$ acidity $=$} & 48.2 & & \multicolumn{2}{|c|}{ Net $\mathrm{N}-\mathrm{P}-\mathrm{K}$ acidity $=$} & 48.7 \\
\hline
\end{tabular}

${ }^{\mathrm{z}}$ Nutrient concentrations in substrate for geraniums and impatiens were means across the two substrates within species.

$\mathrm{N}=$ nitrogen; $\mathrm{P}$ = phosphorus; $\mathrm{K}$ = potassium. 
By difference, fertilizer applications were therefore estimated to contribute $30.7 \mathrm{meq}$ CCE of acidity into the substrate (Fig. 2A).

Acid drench method. Substrate-pH decreased with increasing milliequivalent of $\mathrm{HCl}$ applied. Substrate- $\mathrm{pH}$ decreased as much as 3.49 units in the CHL substrate and 4.32 units in the HL substrate $7 \mathrm{~d}$ after applying the $\mathrm{HCl}$ acid drench (Fig. 3). Using the acidity and $\mathrm{pH}$ response curves shown in Figure 3, the estimated acidity required for similar $\mathrm{pH}$ drops observed in the greenhouse experiment were 43 and $37 \mathrm{meq}$ for the CHL (2.01 units) and HL (2.64 units) substrates, respectively.

Charge balance method. Species resulted in different $\mathrm{N}$ and $\mathrm{P}$ (but not $\mathrm{K}$ ) concentrations in the substrate at Week 6 . The acidity estimate using the charge balance method was therefore calculated separately by species in Table 2. There was 3.5 times more $\mathrm{NH}_{4}-\mathrm{N}\left(55.3 \mathrm{mg} \cdot \mathrm{L}^{-1} \mathrm{SME}\right)$ and nearly twice as much $\mathrm{P}\left(11.5 \mathrm{mg} \cdot \mathrm{L}^{-1}\right)$ remaining in the geranium substrate compared with the impatiens substrate $\left(15.5 \mathrm{mg} \mathrm{NH}_{4}-\mathrm{N} / \mathrm{L}\right.$ and $6.5 \mathrm{mg}$ $\mathrm{P} / \mathrm{L}$ ) (Table 2). There was also 10 times more $\mathrm{NO}_{3}-\mathrm{N}$ remaining in the geranium substrate (33.0 $\mathrm{mg} \mathrm{NH} \mathrm{NH}_{4} \mathrm{~N} / \mathrm{L}$ ) than in the impatiens substrate $(3.1 \mathrm{mg} \mathrm{NH}-\mathrm{N} / \mathrm{L}$ ). There was no nitrate applied through fertigation, so the presence of nitrate in the substrate was assumed to be the result of nitrification. Nitrification has been shown to occur rapidly in container substrates above pH 5.5 (Argo and Biernbaum, 1997; Lang and Elliott, 1991). The lower concentration of nitrate in the impatiens substrate indicates there was either less nitrification or faster nitrate uptake compared with geraniums.

The net estimated acidity applied from N, $\mathrm{P}$, and $\mathrm{K}$ fertilizer was calculated as $50.6 \mathrm{meq}$ $\left(\mathrm{NO}_{3}{ }^{-}=0.0, \mathrm{NH}_{4}{ }^{+}=40.8, \mathrm{P}=-2.3, \mathrm{~K}=12.1\right.$ meq) with $40.8 \mathrm{meq}(80.6 \%)$ from $\mathrm{NH}_{4}-\mathrm{N}$ alone (Table 2). The charge balance method used measured substrate nutrient data to account for nutrients that were applied but not taken up by the plant. Using data collected from the geranium substrate, $\mathrm{N}-\mathrm{P}-\mathrm{K}$ acidity was 48.2 meq $\mathrm{CCE}\left(\mathrm{NO}_{3}{ }^{-}=1.3, \mathrm{NH}_{4}{ }^{+}=\right.$ $38.5, \mathrm{P}=-2.1, \mathrm{~K}=10.5 \mathrm{meq}$ ) with $80.1 \%$ from $\mathrm{NH}_{4}-\mathrm{N}$ uptake alone (Table 2). Using data collected from the impatiens substrate, N-P$\mathrm{K}$ acidity was calculated at $48.7 \mathrm{meq} \mathrm{CCE}$ $\left(\mathrm{NO}_{3}{ }^{-}=-0.3, \mathrm{NH}_{4}{ }^{+}=40.6, \mathrm{P}=-2.3, \mathrm{~K}=10.6\right.$ meq) with $83.4 \%$ from $\mathrm{NH}_{4}-\mathrm{N}$ uptake.

\section{Comparisons between Pierre's method and other methods}

Experimental estimates (summarized in Table 3) indicate that PM overpredicted the potential acidity of the ammonium-based fertilizer used in this experiment. Results of the gasometric, acid drench, and charge balance methods varied by 18 meq between each method. After 20 100-mL, 100-mg. $\mathrm{L}^{-1}$ $\mathrm{N}$ applications of ammonium $\left(100 \% \mathrm{NH}_{4}-\mathrm{N}\right)$ fertilizer, a total $61.8 \mathrm{meq}$ of CCE (acid) per liter of substrate was applied during the course of the 6-week experiment using PM (Table 3). Using other methods, measured CCE acidity values ranged from 30.7 to 48.7

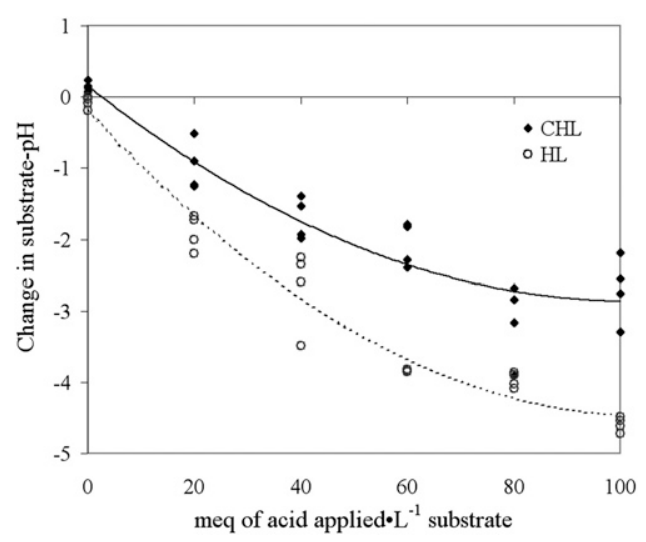

Fig. 3. Change in substrate-pH $7 \mathrm{~d}$ after a single application of $0.5 \mathrm{~N} \mathrm{HCl}$ acid to CHL (containing hydrated and carbonate lime) and HL (hydrated lime only) substrates using the acid drench method. A quadratic curve was fit separately to each substrate type: Change in $\mathrm{pH}$ of $\mathrm{CHL}=0.0002 \mathrm{meq}^{2}-0.0574 \mathrm{meq}+$ $0.0821, R^{2}=0.8907$; change in $\mathrm{pH}$ of $\left.\mathrm{HL}=0.0004 \mathrm{meq}^{2}-0.0839 \mathrm{meq}-0.0812, R^{2}=0.9626\right)$. Each symbol represents a single replicate.

Table 3. Comparison of milliequivalents (meq) of calcium carbonate equivalent (CCE) acidity per liter of substrate estimated using different fertilizer acidity methods when a $10-\mathrm{cm}, 350-\mathrm{mL}$ container received a total of $2 \mathrm{~L}$ of $15.2 \mathrm{~N}-1.9 \mathrm{P}-2.68 \mathrm{~K}$ fertilizer at an $\mathrm{N}$ rate of $100 \mathrm{mg} \cdot \mathrm{L}^{-1}$.

\begin{tabular}{|c|c|c|}
\hline \multirow{3}{*}{$\begin{array}{l}\text { Fertilizer acidity method } \\
\text { Pierre's method }\end{array}$} & \multicolumn{2}{|c|}{ meq of CCE/L of substrate } \\
\hline & & \\
\hline & Geranium & Impatiens \\
\hline Charge balance substrate & $\begin{array}{c}48.2( \pm 2.12)^{\mathrm{z}} \\
\mathrm{CHL}^{\mathrm{y}}\end{array}$ & $\begin{array}{c}48.7( \pm 0.45)^{\mathrm{z}} \\
\mathrm{HL}^{\mathrm{y}}\end{array}$ \\
\hline Gasometric & $30.7( \pm 3.04)^{z}$ & - \\
\hline $\mathrm{HCl}$ acid drench & $43.3( \pm 2.65)^{x}$ & $37.1( \pm 3.15)^{x}$ \\
\hline
\end{tabular}

${ }^{\mathrm{z}}$ Means $\pm 95 \%$ confidence interval $(\mathrm{n}=12)$.

${ }^{\mathrm{y}} \mathrm{CHL}=$ substrate containing hydrated and carbonate lime; $\mathrm{HL}=$ substrate with hydrated lime only.

${ }^{x}$ Means $\pm 95 \%$ confidence interval $(\mathrm{n}=12)$ using $\mathrm{pH}$ measurements collected in a greenhouse experiment.

per L of substrate. Pierre's method, therefore, overestimated the acidity of the ammonium fertilizer by as much as $31.1 \mathrm{meq}$ compared with other methods.

\section{Conclusions}

Three experimental methods were compared with PM. The charge balance method illustrates how the valence of nutrient ions can be used to estimate acidity. However, a weakness of this method was in our calculation of changes in substrate nutrient concentrations during the experiment, because an SME test with deionized water does not measure total nutrients, but only nutrients in the substrate solution. A more complete analysis using the charge balance approach could be applied to other nutrients in addition to $\mathrm{N}, \mathrm{P}$, and $\mathrm{K}$, and indeed that would represent a completely new model that would require further validation. Ions contributed by the substrate itself, $\mathrm{Ca}$ and $\mathrm{Mg}$ from the lime sources, micronutrients and other ions in the fertilizer, irrigation water quality, or other contaminant sources would have some influence on $\mathrm{pH}$ dynamics.

The concept of measuring change in substrate alkalinity was achieved using two approaches. The gasometric method requires a carbonate source (typically limestone) in the substrate and is therefore not appropriate for all substrates (Huang et al., 2007). In addition, once all available carbonate is neutralized, the alkalinity measured with the gasometric method will remain zero even if additional acid continues to be added by fertilizer. The acid drench method would be useful across a wider range of experimental conditions than the gasometric method, and the laboratory-generated $\mathrm{pH}$ response curve means that only $\mathrm{pH}$ measurement is required in subsequent plant experiments for a particular substrate.

We conclude that an alternative estimation of fertilizer acidity or basicity to PM could be developed that more closely represents plant, microbial, and soil chemical processes in soilless substrates with the potential to improve $\mathrm{pH}$ management. To develop such an equation, research and validation would be required. The charge balance-plant uptake and microbial components are particularly sensitive to $\mathrm{N}$, which would therefore be a focus of future research and integration of the wealth of knowledge on cation-anion preference and the $\mathrm{N}$ cycle. An emphasis on $\mathrm{N}$ is also appropriate in terms of expected importance of $\mathrm{N}$ in contributing to $\mathrm{pH}$ effects of fertilizer. Epstein and Bloom (2005) indicate that on average, crop plants take up $1000 \mathrm{~N}$ atoms for every $250 \mathrm{~K}, 50 \mathrm{P}$, 30 sulfur, and three chlorine atoms. This ratio differs greatly from the relative importance of ions estimated using PM for the ammonium fertilizer in this study, whereby contribution to acidity was estimated in the proportions of $24 \% \mathrm{~N}, 18 \% \mathrm{P}, 31 \%$ sulfur, and $27 \%$ chlorine, and $100 \%$ of basicity was 
estimated to result from $\mathrm{K}$. We did not observe differences in $\mathrm{pH}$ response between Pelargonium [an iron-efficient species (Argo and Fisher, 2002)] and Impatiens. However, differences between species in their total nutrient uptake ratios, cation-anion uptake ratio, and iron efficiency may mean that either species-specific parameters would need to be developed for fertilizers or, more realistically, assumptions would be needed to average across multiple species.

There are limits to the accuracy in predicting the $\mathrm{pH}$ effect of a fertilizer based on its chemical formulation only, because multiple factors interact once a fertilizer is applied in plant production (for example, plant species, initial soil $\mathrm{pH}$, residual lime, and so on). By necessity, a series of assumptions would be needed for any estimation. However, an equation could include 1) a charge balance-plant uptake component that considers nutrient ionic charge and valence and relative proportion of uptake; 2) a microbial component, which takes into account the $\mathrm{N}$ cycle process such as nitrification and urea hydrolysis; and 3) a pure chemical component that accounts for $\mathrm{pH}$ reaction of fertilizer and other salts (for example, bicarbonate) in solution. By basing the acidity or basicity on concentration of ions in a nutrient solution rather than a dry fertilizer weight basis, such an equation would more closely represent the $\mathrm{pH}$ dynamics of production in soilless media or with hydroponics. Working on a solution basis would also facilitate balancing alkalinity of an irrigation water source with the acidity of the fertilizer to develop an overall neutral $\mathrm{pH}$ response of the overall nutrient solution. However, the same equation could also be adapted for controlled-release, slow-release, and granular fertilizers applied as solids to soilless substrates.

\section{Literature Cited}

Andrews, W.B. 1954. The response of crops and soils to fertilizers and manures. 2nd Ed. William Byrd Press, Inc., Richmond, VA.

Argo, W.R. and J.A. Biernbaum. 1997. Lime, water source, and fertilizer nitrogen form affect medium $\mathrm{pH}$ and nitrogen accumulation and uptake. HortScience 32:71-74.

Argo, W.R. and P.R. Fisher. 2002. Understanding $\mathrm{pH}$ management for container-grown crops. Meister Publishing, Willoughby, $\mathrm{OH}$.

Association of Official Analytical Chemists (AOAC). 1970. Official methods of analysis. 11 th Ed. AOAC International, Washington, DC.

Association of Official Analytical Chemists (AOAC). 1999. Official methods of analysis. 16th Ed. AOAC International, Gaithersburg, MD.

Bailey, D.A. 1996. Alkalinity, pH and acidification, p. 69-91. In: Reed, D.W. (ed.). Water, media, and nutrition for greenhouse crops. Ball Publishing, Batavia, IL.

Engels, C. and H. Marschner. 1995. Plant uptake and utilization of nitrogen, p. 41-82. In: Bacon, P.E. (ed.). Nitrogen fertilization in the environment. Marcel Dekker, Inc., New York, NY.

Epstein, E. and A.J. Bloom (eds.). 2005. Inorganic components of plants, p. 41-66. In: Mineral nutrition of plants: Principles and perspectives. 2nd Ed. Sinauer Associates, Inc., Sunderland, MA

Hignett, T.P. (ed.). 1985. Physical and chemical properties of fertilizers and methods for their determination, p. 284-316. In: Fertilizer manual. Martinus Nijhoff/Dr W. Junk Publishers, Dordrecht, The Netherlands.

Horat, L.E. 1939. Report on acid- and base-forming quality of fertilizers. Journal of the AOAC 19:289-297.

Huang, J., P.R. Fisher, and W.R. Argo. 2007. A gasometric procedure to measure residual lime in container substrates. HortScience 42:16851689.

Huang, J., P.R. Fisher, W.E. Horner, and W.R. Argo. 2009. Limestone particle size and residual lime concentration affect $\mathrm{pH}$ buffering in container substrates. J. Plant Nutr. 33:846-858.
Lang, H.J. and G.C. Elliott. 1991. Influence of ammonium: Nitrate ratio and nitrogen concentration on nitrification activity in soilless potting media. J. Amer. Soc. Hort. Sci. 116:642645.

Lewis, O.A.M. 1986. Plants and nitrogen. Edward Arnold, Baltimore, MD.

Marschner, H. 1995. Mineral nutrition of higher plants. 2nd Ed. Academic Press, San Diego, CA.

Pierre, W.H. 1933. Determination of equivalent acidity and basicity of fertilizers. Ind. Eng. Chem. 5:229-234.

Puustjarvi, V. and R.A. Robertson. 1975. Physical and chemical properties, p. 23-38. In: Robinson, D.W. and J.G.D. Lamb (eds.). Peat in horticulture. Academic Press, London, UK.

Rippy, J.F.M. and P.V. Nelson. 2005. Soilless root substrate $\mathrm{pH}$ measurement technique for titration. HortScience 40:201-204.

SAS Institute. 2001. SAS/STAT user's guide. Version 8.2. SAS Institute, Inc., Cary, NC.

Tisdale, S.L., J.L. Havlin, J.D. Beaton and W.L. Nelson (eds.). 1999. Soil acidity and alkalinity, p. 38-85. In: Soil fertility and fertilizers. 6th Ed. Prentice Hall, Upper Saddle River, NJ.

Tisdale, S.L. and W.L. Nelson. 1966. Soil fertility and fertilizers. 2nd Ed. Macmillan Company, New York, NY

Touraine, B., F. Daniel-Vedele, and B.G. Forde. 2001. Nitrate uptake and its regulation, p. 1-36. In: Lea, P.J. and J.-F. Morot-Gaudry (eds.). Plant nitrogen. Springer, New York, NY.

von Wiren, N., A. Gojon, S. Chaillou, and D Raper. 2001. Mechanisms and regulation of ammonium uptake in higher plants, p. 61-77. In: Lea, P.J. and J.-F. Morot-Gaudry (eds.). Plant nitrogen. Springer, New York, NY.

Warncke, D.D. 1986. Analyzing greenhouse growth media by the saturation extraction method. HortScience 21:223-225.

Warncke, D.D. 1995. Recommended test procedures for greenhouse growth media. In: Recommended soil testing procedures for the northeastern United States. 2nd Ed. Univ. of Delaware Agricultural Experiment Station Bulletin 493:76-83. 